\title{
Ecological Effects of Channelization on a Tropical Marine Ecosystem: Impact on Intertidal Fish Communities in the Cross River, Nigeria
}

\author{
I. O. Ewa-Oboho \\ Marine Biology/Ecological Unit, Institute of Oceanography, University of Calabar, P.M.B 1115, Calabar, Nigeria
}

\begin{abstract}
The impact of bulk density silt/clay sedimentation from dredging in the Cross River Estuary (S. E. Nigeria) on fish was assessed through the use of community structural analysis and ecological procedures emphasizing reproduction and feeding characteristics. The distinction among the channel, creeklet and pool fish communities decreased as the percentage of silt/clay substrate increased. The abundance of benthic invertivore and herbivore fish groups declined significantly, as the percentage of silt increased for the channel fish dwellers. This is because the simple and lithophilous reproduction category requires clean and coarse substrates for spawning. All species affected by increased silt sedimentation within a guild were significantly similar in trends of abundance. The ecological implication of these findings is the similar response of fish species of similar ecological niches to excessive turbidity.
\end{abstract}

\section{Introduction}

In 1996-1998 when the Cross River Estuary (the largest in Africa) was dredged to deepen the channel, there were large volumes of suspended organic particles in the estuary and its adjacent tidal creeks. The increased sedimentation of silty components in the neighbouring tidal creeks and water pools destroyed and reduced niche species of native fish and in turn reduced production and diversity (Hilary et al., 1987; Holzlohner et al., 2002; Spalding, 1997). Excessive siltation from running water and erosion into nearby creeks and streams have been considered to be a very important factor limiting usable fish habitat in such systems (Judy et al., 1984; Sheridan et al., 2002). This has not been substantiated quantita-tively for a scientific clarification of the biological/ecological basis of these impacts.

Low level chronic impacts of this type are detected and measured by the use of the community functional analysis (Cairns \& Dickson, 1980; Hendricks et al., 1980; Stauffer \& Hocutt, 1980; Karr, 1981). A study of how siltation affects fish nutrition and reproduction is critical, because the primary effects of increased sedimentation on estuarine fish are believed to be the disruption of normal reproduction and food supply (Ellis, 1936; Cordone \& Kelley, 1961; Allen, 1969; Karr \& Dudey, 1981; Hendri, 1998; Asuquo et al., 2004).

The objectives of this study were to (i) quantify the impact of excessive siltation on intertidal creek fishes in the creeklets and waterways of the Cross River Estuary, and (ii) examine the ecological implications of the impacts of sedimentation on fish fauna in general with particular reference to effects on reproduction and feeding habits.

\section{Study area}

\section{Materials and methods}

The Cross River Estuary ( $4^{\circ} 00^{\prime}$ and $8^{\circ} 00^{\prime} \mathrm{N}$ and $7^{\circ} 20^{\prime}$ and $10^{\circ} 00^{\prime} \mathrm{E}$ ) is located on the south-eastern end of Calabar in the south-east of Nigeria and is part of the shallow (4-15 m depth) area, $5.5 \mathrm{~km}$ wide (Fig. 1). The climate is of the equatorial type, always hot and wet. During the period November-April, the region lies in the high pressure belt from which the trade winds start and is dry. From May-October, the region is under the influence of the monsoon winds and form a continuation of the south-east trade winds. These bring heavy rainfall to the area. The climate and hydrology have been reported (Asuquo, 1998). 


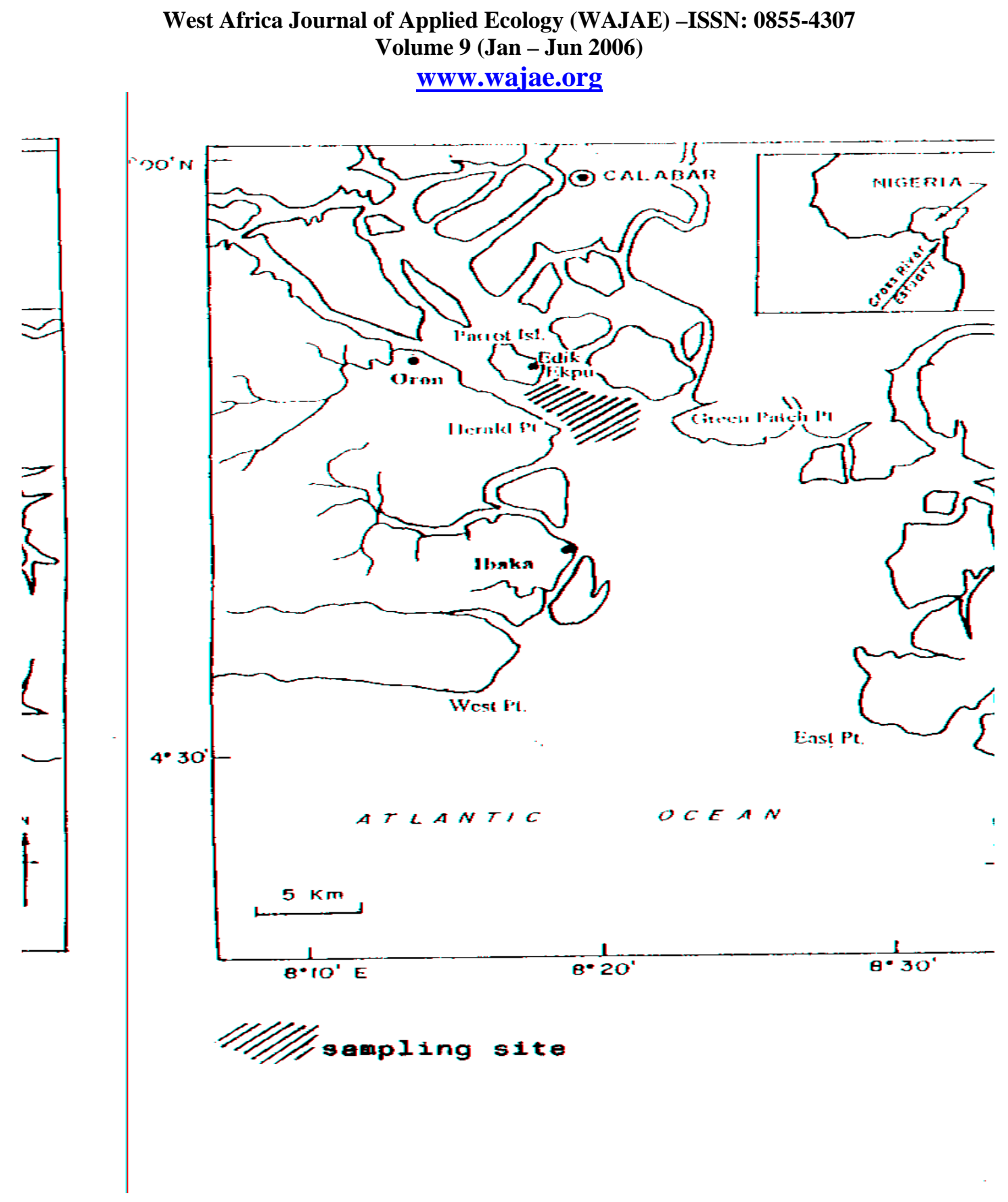

Fig. 1. Map of Cross River Estuary showing the sampling sites

- $\quad$ The mean percent silt for creeklet was 12.5 (SD 2.4) and for pools 20.8 (SD.2.6)

Environmental parameters

Ten sampling stations which ranged from $45 \mathrm{~m}$ to $110 \mathrm{~m}$ long $(\mathrm{x}=82.5 \mathrm{~m})$ and approximately $20 \mathrm{~m}$ wide were established. One location on each creek consisted of a creeklet and a pool. Fish habitats were defined by current velocity and depth at the time of fish sampling which was during mid tide. Measurements of the width and depth were taken at approximately $5 \mathrm{~m}$ and $0.1 \mathrm{~m}$ intervals along transects across each creeklet. Three current velocity readings were taken across the channels with a Gurley-Pygmy current meter at the midpoint of each of three transects within each habitat at $7 \mathrm{~m}$ of the total depth (Table 1 ). 


\section{West Africa Journal of Applied Ecology (WAJAE) -ISSN: 0855-4307 \\ Volume 9 (Jan - Jun 2006) \\ www.wajae.org \\ TABLE 1}

Physical Characteristics of the study channels in three mains areas of the Cross River estuary - (1998)

\begin{tabular}{|c|c|c|c|c|c|c|c|c|c|c|c|c|c|c|}
\hline \multirow{2}{*}{$\begin{array}{l}\text { Creeks \& Location with } \\
\text { Height above Datum (m) }\end{array}$} & \multicolumn{3}{|c|}{ Current speed $\left(\mathrm{cm} \mathrm{sec}^{-1}\right)$} & \multicolumn{3}{|c|}{ Depth (m) } & \multicolumn{3}{|c|}{ Width } & \multicolumn{2}{|c|}{ Percentage silt } & \multirow{2}{*}{\multicolumn{3}{|c|}{$\begin{array}{l}\text { Estimate available } \\
\text { organic matter (\%) }\end{array}$}} \\
\hline & $X$ & $S D$ & $N$ & $X$ & $S D$ & $N$ & $X$ & $S D$ & $N$ & $X$ & $\begin{array}{l}S D \\
\mathrm{~N}=3\end{array}$ & & & \\
\hline \multicolumn{15}{|l|}{ Creek town Creek } \\
\hline 1 & 48 & $\begin{array}{l}16 \\
1.6\end{array}$ & 3 & 15 & & 3 & & 16 & 18 & 4 & 3 & 6.5 & & 2.6 \\
\hline 2. & 56 & $\begin{array}{l}24 \\
1.2\end{array}$ & 3 & 10 & & 2 & & 16 & 20 & 5 & 3 & 4.5 & & 3.8 \\
\hline 3. & 55 & $\begin{array}{l}24 \\
1.2\end{array}$ & 3 & 10 & & 2 & & 15 & 20 & 5 & 3 & 8.8 & & 3.2 \\
\hline 4. & 51 & $\begin{array}{l}20 \\
1.4\end{array}$ & 4 & 9.6 & & 3 & & 15 & 18 & 4 & 3 & 4.4 & & 3.5 \\
\hline \multicolumn{15}{|l|}{ Tobacco Island Creek } \\
\hline 1 & 32 & $\begin{array}{l}12 \\
1.0\end{array}$ & & 10 & & 2 & & 14 & 16 & & & 4 & 2.8 & 2.1 \\
\hline 2 & 38 & $\begin{array}{l}18 \\
2.5\end{array}$ & & 11 & & 2 & & 11 & 22 & & & 3 & 3.2 & 1.8 \\
\hline 3 & 23 & $\begin{array}{c}9 \\
1.6\end{array}$ & & 7 & 1.3 & & 15 & 30 & & & 6 & 4.6 & & 4.2 \\
\hline \multicolumn{15}{|l|}{ Greek Kwa Creek } \\
\hline 1 & $\begin{array}{l}35 \\
1.5\end{array}$ & 15 & 6 & 10 & 2.2 & 13 & 15 & & & & 4 & 0.0 & & \\
\hline 2 & 60 & 28 & 4 & 12 & 3 & & 10 & 18 & & 4 & 3.0 & 3.2 & & 1.0 \\
\hline 3 & 68 & 31 & 4 & 10 & 2 & & 24 & 13 & & 3 & 2.1 & 2.1 & & 0.9 \\
\hline
\end{tabular}

Sediment samples were taken at random at each representative transect in each habitat type using a fibre glass core sampler, $8 \mathrm{~cm}$ in diameter, and penetrating to a depth of $5 \mathrm{~cm}$. Substrate samples with the accompanied creek water were stored in 1 litre plastic bottles and taken to the laboratory for air drying and analysis for sediment particle size, and determination of percentage dry weight of silt-sized particles $(0.0625 \mathrm{~mm})$.

\section{Fish sampling}

In April and May 1998, fish samples were collected from three locations each of three creeks in the Cross River estuarine system-Creek Town creek, Great Kwa river and Tobacco Island creek. Sites were selected to minimize possible geographic and hydrologic variables. Five down stream sweeps were undertaken in water pools, channel and creeklets using a $4 \mathrm{~mm}$-mesh minnow seine net. In shallower areas fish were obtained by placing seine nets at the downstream end to catch and collect fish released by beating water with a stick and over turning logs and weeds in the upstream section of the creeks. Ten beat samples were taken in each creek channel. Apart from seining at each site, electro-fishing samples were collected a week later at the same site using a $110 \mathrm{~V}$ DC battery-operated back pack electro-fisher for a timed collection period with similar effort per unit of area in each habitat type. Collected fish were identified to species level, counted and separated into young and adult groups based on length frequency analysis of combined total of all fish electro-fished or retained by the 4-mm mesh seine.

\section{Statistical analysis: classification and ordination of samples}

Ordination statistics was used to assess similarities in species composition and relative abundance of fish in different communities. In the present study, fish species was the coarse variable. Communities that are similar in species and abundance were grouped together while dissimilar communities were grouped and placed further apart (Rabeni \& Gibbs, 1980). A modified reciprocal averaging (Hill, 1979; Culp \& Davis, 1980) known as detrended correspondence analysis (Gauch, 1982) was the type of ordination applied using the Fortran programme TWIN-SPAN (Hill, 1979). DECORANA, a Cornell Ecology Programme (Hill, 1979) was applied to produce the plot. Details of TWINSPAN and its performance can be found in Hill (1979) and Gauch (1982). 


\section{West Africa Journal of Applied Ecology (WAJAE) -ISSN: 0855-4307 \\ Volume 9 (Jan - Jun 2006) \\ www.wajae.org}

Fish species collected in over 50\% of the sample or represented by more than 50 individuals from all samples were termed common and categorized by habitat preference. Individuals of species were categorized into habitat specific types according to their level of dominance in that habitat, i.e. creeklet, shallow channel and pool-type. Fish species that did not dominate in number in any of the types of habitat were referred to as universal. Creek channels and pools were used to relate fish commu-nities to substrate characteristics because these habitats were readily subjected to sedimentation.

Ecological functions within a community were estimated by the abundance (catch per unit effort) and relative abundance (per-centage of total) of individuals of different feeding and reproductive groups present in various habitats of different sedimentation rates. Fish species were categorized into any four feeding types, defined by specific food and feeding behaviour: (1) omnivores, which consumed animals, plants and detrital material; (2) general insectivores, which consume surface, midwater and benthic insects; (3) benthic insectivores, which consume only benthic insects; (4) herbivores, which consume plant material. The other invertevores/piscivore which were less than $5 \%$ of total fish collected were not included in the final analysis.

A hierarchical classification designed by Muncy et. al. (1999) separates fish first into simple and complex spawners based on availability of spawning site, territorial defense and social behaviour. The complex spawners were further divided based on whether or not parental care was observed. The simple spawners were sub-categorized into spawning substrate need such as submerged vegetation, partially submerged structures, on sand and on silt. Fish species were assigned to one o the groups as shown in Table 2.

TABLE 2

Occurrence of fish species in the Cross River Estuarine system with an index of ecological type (group): $1=$ herbivore; $2=$ omnivore; $3=$ insectivore; 4 = benthic insectivores; reproductive groups, 5 = simple; $5 a$ = simple miscellaneous; $5 b=$ complex parental care, (lithophilous); $5 c=$ no parental care $; 6$ creeks; 7 = pool; 8 = channel; $9=$ ubiquitous. Habit assignments were made only for species that were designated as common.

Speciescrophic

\section{Cichlidae}

Tilapia guineensis (Becker 1862)

Sarotherodon melanotheron (Rupell 1052)

Gibiidae

Porogobius schlegeli (Giinther 1861)

Yongeichthys thomasi (Boulenger, 1916)

Cyprinidae

Aplocheilichyhys spilaunchem

Eleotridae

Bostrychus africanus Steidchner 1870

Eleotris Vittata Dumeril 1958

Prionobutis sp.

\section{Clupeidae}

Pellonula leonensis

Clupeidae

Sardinella maderensis

\section{Clupeidae}

Sardinella maderensis

Elopidae

Elops lacerta

\section{Category}

1

4

2

4

4

4

3
Reproductive
Category

5

$5 a$

5.5

5

$5 b$

$5 a$

6,8
6,7

Habit

Assignment

9

6,7

6,7

6,7

6,7 


\title{
West Africa Journal of Applied Ecology (WAJAE) -ISSN: 0855-4307 \\ Volume 9 (Jan - Jun 2006) \\ www.wajae.org
}

Bagriidae

Chrysichthys nigrodigitatus

\author{
Mugilidae \\ Sphyrarena guachancho \\ Ethmalosa fimbriata \\ Liza grandisquamus \\ Mugil cephalus \\ Ilisha africana
}

$\begin{array}{cll}3 & 5 & 8 \\ 1 & 5 & 8 \\ 2,4 & 5 & 8 \\ 1,2 & 5 & \\ & 5 & 6,8\end{array}$

To determine the effect of sedimentation on estuarine fish species of the Cross River system, the correlations between the quantity of siltation and the relative abundance of individual species within each ecological habitat was determined using the non parametric Spearman rank correlation statistics (Siegel, 1956). The amount of silta-tion and the relative abundance, as well as the absolute abundance (catch per unit effort) of individuals within each guild was also determined. The reproductive and feeding groups which correlated significantly with sedimentation levels were further analyzed for correlation of abundance between their component species for inference of species having similar abun-dance patterns.

\section{Results}

The different habitats of creeks, pools and channel inundated mudflats had characteristics which ecologically influenced the predominant fish species inhabiting them. The main channel had current velocity ranging between 23 and $68 \mathrm{~cm} \mathrm{sec}^{-1}\left(x=0.6 \mathrm{~cm} \mathrm{sec}^{-1}\right)$ and depths of $10-15 \mathrm{~m}(x=11.8 \mathrm{~cm})$ (Table 1). Pool current velocity ranged from $>1 \mathrm{~cm} \mathrm{sec}^{-1}$ to $2.5 \mathrm{~cm} \mathrm{sec}^{-1}\left(x=0.05 \mathrm{~cm} \mathrm{sec}^{-1}\right)$ with depth of 3.8-10.5 m $(x=6.2 \mathrm{~m})$. Creeklets were narrower $(x=2.8$ $\mathrm{m} \mathrm{SE}=0.93$ ) than pools $x=6.8 \mathrm{~m} \mathrm{SE}=1.3$ with velocity varying from 20 to $55 \mathrm{~cm} \mathrm{sec}^{-1}$ and depths ranging from 2$4 \mathrm{~m}(x=2.8 \mathrm{~m})$.

The percentage sedimentation of silt by weight of the channel substrate ranged from 0.0 to 6.5 with a mean of 3.5, while the mean percentage siltation for creeklets and pool was 12.5 ( $\mathrm{SE}=7.8)$ and 21.8 (SE = 18.6), respectively. Dead mangrove debris characterized all the sites, particularly the pools and the creeklets. In the Cross River system, it was found that the different habitat types supported distinct fish assemblages as in many tropical aquatic ecosystems (Gorman \& Karr, 1978; Moyle \& Senanayake, 1984). Many species exhibited preferences for a particular habitat type: main channel, creeklet or pool. No species was collected from only one habitat type and only $25 \%$ of the common species did not have most of their individuals from a single habitat type.

The habitat preferences of species are shown on the multi-dimensional scaling ordination (Fig. 2). Here, the pool fishes are grouped nearest the origin of the graph, the main channel fish species farthest while the creeklet fish communities are intermediate. The aggregation of the pool habitats depicted a similarity of species and relative abundances. Generally, the number of species recorded in the study was small (Table 1), but eight groups of fish were of particular importance, accounting for $98 \%$ of the total number sampled in the various habitats. The pools were dominated by the cichlids (Tilapia guineesis) (Bleeker, 1862), the gobids Porogobius schlegeli (Gunther, 1861) and the cyprinid Aplocheilichys spilaunchem (Dumeril, 1859). The creeklets were dominated by the ubiquitous Tilapia guineesis and Yongeichthys thomasi, (Boulenger 1916), Sarotherodon melanotheron (Rupell, 1852) Eleotris vittata, (Dumeril, 1858); while the main channels/inundated mudflats were predominantly Chrysichthys nigrodigitatus, Liza sp, T. guineesis, Ethmalosa fimbriata and lllsha africana (Table 3). The species diversity of the three habitat types was low (Shannon Diversity Index, $\mathrm{H}^{1}=0.21,0.36$ and 0.48 for the pool, creeklets and channels respectively. The more dispersed pattern of the channel sites on the ordination indicates more diversity in community structure among these habitat types. 
West Africa Journal of Applied Ecology (WAJAE) -ISSN: 0855-4307

Volume 9 (Jan - Jun 2006)

www.wajae.org

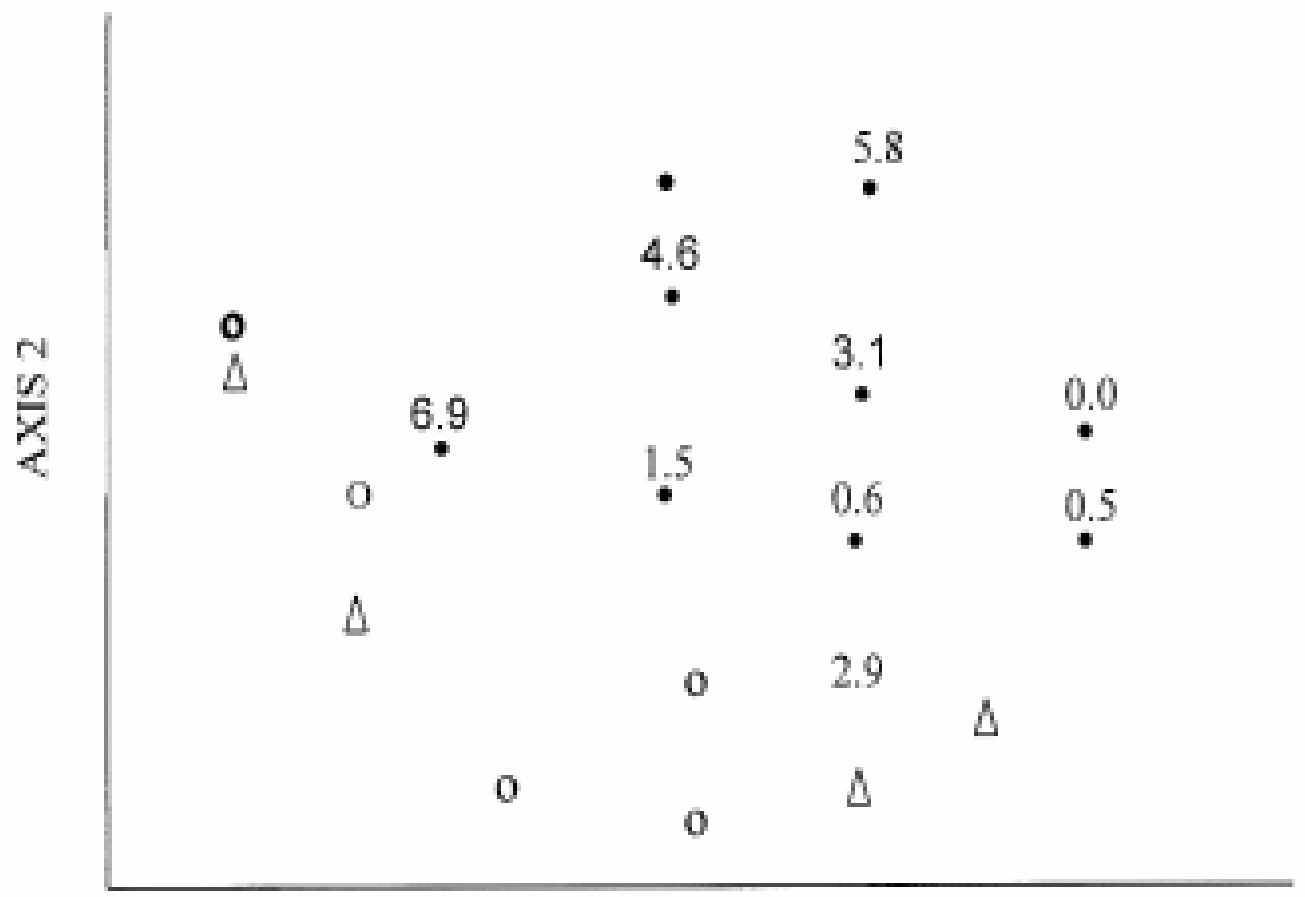

\section{AXIS 1}

Fig. 2. Ordination of fish communities from the three principal habitat types. Values refer to average percentage silt at Channel Sampling stations •Channel; o Pool; D Creeklets.

TABLE 3

Relative abundance ranking for common species (fish obtained in $>50 \%$ of samples) from channels, creeklets and pools. The habitat designation of species from Table 2 are in parenthesis, channel $=8$, pool $=7$, creeklet $=6$, ubiquitous $=9$.

\begin{tabular}{|c|c|c|c|c|}
\hline $\begin{array}{l}>5 \% \text { silt } \\
(N=10)\end{array}$ & $\begin{array}{l}\text { Channel } \\
5-8 \% \text { silt } \\
(N=6)\end{array}$ & $\begin{array}{l}>8 \% \text { silt } \\
(N=3)\end{array}$ & $\begin{array}{l}\text { Creeklet } \\
X=15.2 \% \text { silt } \\
(N=8)\end{array}$ & $\begin{array}{l}\text { Pool } \\
X=25-6 \% \\
(N=13)\end{array}$ \\
\hline $\begin{array}{l}\text { Ethmalosa fimbriata (8) } \\
\text { (6) } \\
\text { (9) }\end{array}$ & Cynoclossus sp (9) & $\begin{array}{l}\text { Chrysichthys sp (9) } \\
\text { nigrodigitatus }\end{array}$ & Eleotris vittata (6) & $\begin{array}{l}\text { Progobitus schlegeli } \\
\text { Tilapia guineneensis }\end{array}$ \\
\hline Tilapia guineensis (9) & $\begin{array}{l}\text { Sardinella } \\
\text { madrensis (8) }\end{array}$ & $\begin{array}{l}\text { Sarotherodon } \\
\text { melanotheron (7) }\end{array}$ & $\begin{array}{l}\text { Sarotherodon } \\
\text { melanotheron (7) }\end{array}$ & $\begin{array}{l}\text { Yongeichthys } \\
\text { thomasi (9) }\end{array}$ \\
\hline Lujanus sp. (8) & $\begin{array}{l}\text { Chrysichthys } \\
\text { nigrodigitatus (9) } \\
\text { Ilisha africana (8) }\end{array}$ & Cynoclossus & Parogobius schlegeli (7) & $\begin{array}{l}\text { Aplocheilichthy } \\
\text { spilaunchem (7) } \\
\text { Bostrychus } \\
\text { africanus (7) }\end{array}$ \\
\hline Cynoclossus & Tilapia guineensis (9) & Yongeichthys thomasi (7) & $\begin{array}{l}\text { Pellonula leonensis (6) } \\
\text { Heterotis niloticus (6) }\end{array}$ & \\
\hline
\end{tabular}




\section{West Africa Journal of Applied Ecology (WAJAE) -ISSN: 0855-4307 \\ Volume 9 (Jan - Jun 2006) \\ www.wajae.org}

The upper most end of the ordination was anomalous because of the seasonally high percentage of Ethmalosa fimbriata species at this time of the study, which, when combined with more usual channel fish, gave a unique species assemblage. Otherwise, there is a relation between channel placement on the plot and the amount of silt (\%) at those locations. The channel had the highest silt loads being that dredging was directly done on a major waterway close to the smaller mudflat channels, followed by the creeklets and the pools. There was also a corresponding change in fish community structure. Channel-dominated species were found in small numbers in these high silt habitats while low silt habitats were devoid of channel-specific fish species. This relationship between $\%$ silt and $\%$ channel dwelling fish was significantly correlated (Spearman's $\mathrm{Y}_{\mathrm{s}}=0.78 \mathrm{p}>0.01$ ).

The relative abundance rankings of species from channels with different debris loads (Table 3) showed that as sedimentation increased, fish community dominance changed from channel-specific species to the common and creeklet-specific ones so that the high-silt channels have fish communities closely resembling those of the average creeklet and pool than those of the low silt channels.

The major differences in species abundance and occurrence between pool-creeklet communities and the highly siltimpacted channel were the absence of $P$. schlegeli; $Y$. thomasi and A. spilaunchem from the channels. T. guineensis, a common pool specific species, was only regularly found in channels with low silt loads. The homogeneity of the environment due to the impact of dredging activities are the cause of the observed structural changes in fish species composition, as the environment of channel-creeklet could be likened to a single continuous habitat. No clear relation was observed between creek and pool communities with increased siltation as was clearly noticed with the channel dwellers, which were ultimately examined for the effect of increased silt on fish with different feeding habitats (Table 4). As siltation increased, the trophic structure of the channel community altered.

TABLE 4

Correlation coefficient ( $Y$ (Spearman's rank) between percentage of silt in channels and fish abundance, and relative abundance

\begin{tabular}{|c|c|c|c|}
\hline \multicolumn{2}{|c|}{ Ecological characteristics } & \multirow{2}{*}{$\begin{array}{l}\text { Abundance } \\
*=P \leq 0.01 \\
\text { Absolute }\end{array}$} & \multirow{2}{*}{$\begin{array}{l}\text { Significant level } \\
*=P \leq 0.05\end{array}$} \\
\hline Feeding type & Relative & & \\
\hline Herbivore & $-0.92 *$ & $-12 * *$ & \\
\hline Omnivore & & 0.60 & 0.36 \\
\hline Benthic Inver & vore & $-0.74 *$ & $-68 * *$ \\
\hline \multicolumn{4}{|c|}{ Reproductive type } \\
\hline Simple and lit & ophilous & $-0.79 *$ & $-0.75^{* *}$ \\
\hline Complex - $\mathrm{Pa}$ & ental Care & 0.03 & 0.11 \\
\hline No- parental & are & 0.46 & 0.18 \\
\hline
\end{tabular}

The relative abundance of benthic insectivore increased ( $\mathrm{rs}, \mathrm{P} \leq 0.05$ ) while herbivores decreased ( $\mathrm{rs}, \mathrm{P} \leq 0.05$ ), leading to changes in community structure of the fish species. There was no significant positive correlation between siltation and any guild. As dredging continued and sedimentation of silty materials increased, the relative abundance of the simple and lithophilous reproductive guild decreased while that of the simple and miscellaneous increased (rs, $\mathrm{P}$ $\leq 0.05$ ). The percentage alteration in the complex guilds was slight. This change was ascribed to increased siltation due to decrease in absolute number of simple and lithophilous guilds (rs, $\mathrm{P} \leq 0.05$ ).

Significant correlation was not shown with any other guild. To measure the environmental effect of the sedimentation due to dredging using the guild concept, the species within guilds that correlated significantly with sedimentation levels should show the same trends in abundance. The correlation coefficient matrix (Table 5) showed that all fish species feeding guilds most highly correlated with sedimentation (benthic insectivores and herbivores) were significantly and positively correlated with at least one other species in these guilds, and three of the six species were significantly and positively correlated with the other half of the remaining species in these guilds. The simple and lithophilous reproductive guild was the only reproductive guild significantly correlated with sedimentation. 


\section{West Africa Journal of Applied Ecology (WAJAE) -ISSN: 0855-4307 \\ Volume 9 (Jan - Jun 2006) \\ www.wajae.org}

\begin{tabular}{|c|c|c|c|c|c|c|c|c|c|c|c|c|}
\hline & 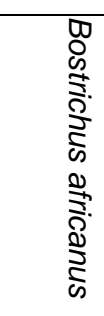 & 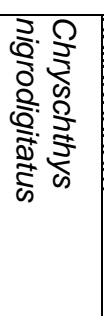 & 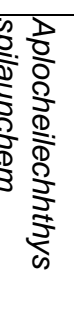 & 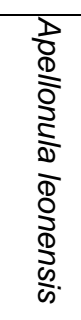 & 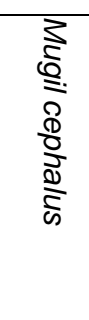 & 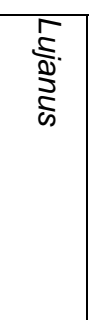 & 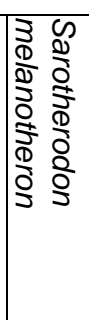 & 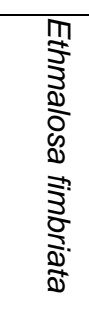 & 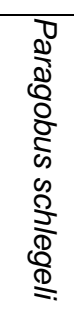 & 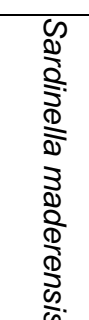 & 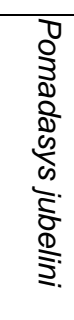 & 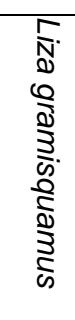 \\
\hline $\begin{array}{l}\text { Bostrychus africanus } \\
\text { Chryschthys nigrodigitatus } \\
\text { Aplocheilechhthys spilaunchem } \\
\text { Apellonula leonensis } \\
\text { Mugil cephalus _- } \\
\text { Lujanus } \\
\text { Sarotherodon melanotheron_- } \\
\text { Ethmalosa fimbriata }\end{array}$ & $\begin{array}{l}.78^{*} \\
.32 \\
.50 \\
.48 \\
.22 \\
.76 \\
.62\end{array}$ & $\begin{array}{l}.38 \\
.62 \\
.51 \\
.28 \\
.81 \\
.69\end{array}$ & $\begin{array}{l}. .4 \\
.58 \\
.38 \\
.06 \\
.15\end{array}$ & $\begin{array}{l}-36 \\
-.49 \\
.70 \\
.62\end{array}$ & $\begin{array}{l}42 \\
.51 \\
.40\end{array}$ & $\begin{array}{l}.42 \\
.05 \\
.05 \\
.02\end{array}$ & $\begin{array}{l}.79 \\
.05 \\
79\end{array}$ & $\begin{array}{l}.40 \\
.02 \\
79\end{array}$ & $\begin{array}{l}.12 \\
.08 \\
.58\end{array}$ & $\begin{array}{l}.18 \\
.08 \\
.36 \\
.60\end{array}$ & $\begin{array}{l}.46 \\
.68^{*} \\
-.21 \\
.32 \\
-18\end{array}$ & \\
\hline $\begin{array}{l}\text { Parogobus schlegeli } \\
\text { Sarodinella maderensis } \\
\text { Pomadasys jubelini } \\
\text { Liza gramisquamus }\end{array}$ & $\begin{array}{l}.65^{\star} \\
.16 \\
-.31 \\
-.24\end{array}$ & \begin{tabular}{l|}
$.67^{\star}$ \\
.24 \\
-.03 \\
$.12^{\star \star}$
\end{tabular} & $\begin{array}{l}.48 \\
.36 \\
.50 \\
.18\end{array}$ & $\begin{array}{l}.08 \\
01 \\
.42 \\
.64\end{array}$ & $\begin{array}{l}.21 \\
.05 \\
-.35 \\
05\end{array}$ & $\begin{array}{l}.16 \\
.10 \\
.09 \\
-.51\end{array}$ & $\begin{array}{l}-.26 \\
.12 \\
.10 \\
.36\end{array}$ & $\begin{array}{l}0.08 \\
.26 \\
-.31 \\
-.18\end{array}$ & $\begin{array}{l}.19 \\
-34 \\
-.66 \\
-45\end{array}$ & $\begin{array}{r}.42 \\
.28 \\
.23 \\
.13\end{array}$ & $\begin{array}{l}.21 \\
.23 \\
.41 \\
.- \\
.24\end{array}$ & $\begin{array}{l}.08 \\
-.44 \\
.36\end{array}$ \\
\hline
\end{tabular}

${ }^{*} \mathrm{P}<0.01$

** $\mathrm{P}<0.05$

Also observed was a greater percentage of correlations $(\mathrm{P} \leq 0.1)$ of abundance of species pairs; within the guilds that were significantly correlated with silt levels. Correlations within a combination of benthic insectivore and herbivore guilds were significant for $35 \%$ of the possible pairs, within the simple and lithophilous guild, correlations were significant for $23 \%$ of the total pairs. These percentages were both greater than what would be expected by chance $\left(\mathrm{X}^{2}\right.$ $=$ test $=48.89, \mathrm{df}=1, \mathrm{P} \leq 0.01)$ value. Fish species from guilds not significantly correlated, was not more than would be expected by chance $\left(\mathrm{X}^{2}, \mathrm{P} \mathrm{X}^{2}=12.07, \mathrm{df}=1, \mathrm{P} \leq 0.01\right)$.

\section{Discussion}

This is the first attempt to assess the possible effect of channelization activities on ecosystem bio-components. It is not an easy task to separate the influences of anthropogenic activities, e.g. removal of fine sand for sale by local inhabitants, clearing and timbering activities on the mangrove vegetation, etc. from the effect of sedimentation of silty debris. Besides, natural factors such as temporal and spatial variations in tidal flow regimes, size of creeks, and zoogeographic factors, which were minimized by selection of creeks that were similar in flow patterns, would complicate findings. The temporal factors influencing community structure in the estuary (e.g. spates or drought) should have affected all sites similarly, thus, the variable of substrate particle size was isolated. It is shown in this study that as silt sediment increased the differences among channel, creek and pool fish decreased because the abundance of many channel species decreased. Certain physical characteristics of the ecosystem have been related to fish diversity in estuarine systems. These include depth, substrate type and flow pattern (Gorman \& Karr 1978).

The substrate type was critical in the present study, because even the main-tenance of characteristics current speed and depth were not sufficient to retain the integrity of the typical channel fish community if the percentage of fine particle sizes increased. From this study, it can be stated that fish with similar feeding and reproductive strategies are equally influenced by silt sedimentation. These relationships when examined biologically are rational. The feeding strategies most negatively correlated with siltation were those most specialize to feed from the bottom sediment. Benthic feeders were critically affected. This is in agreement that increased silt sedimentation reduces the abundance 


\section{West Africa Journal of Applied Ecology (WAJAE) -ISSN: 0855-4307 \\ Volume 9 (Jan - Jun 2006) \\ www.wajae.org}

of benthic invertebrates and species diversity and richness. (Chutter, 1969; Brusven \& Prather, 1974; Ewa-Oboho, 1992). The decrease in abundance of the herbivorous fish $T$. guineensis as a result of increased silt sedimentation may be ascribed to the effect of turbidity and scouring on algal production, besides the development of unstable substratum for attachment.

Previous studies (Schlosser, 1982, Ewa-Oboho, 1992) have shown that increased algal and invertebrate production is followed by a correlated increase in growth, reproductive success and recruitment of fish species in similar ecosystems. The inver-tivores and omnivores, which were not correlated with silt sedimentation, are more or less opportunistic in their foraging behaviours and may be capable of modifying their feeding habit so as not to be foodlimited (Starrett, 1950). Alterations in breeding and spawning conditions as a result of increased siltation, could be very fatal to fish. Prolonged siltation degrades spawning grounds, causes behavioural changes in spawning fish, increases egg mortality, decreases larval growth, and affect rate of larval development and survival of larval fish (Langlois, 1941; Cordone \& Kelley, 1961; Smith, 1971; Muncy et al. 1999; Ewa-Oboho, in press). It is, therefore, reasonable that the reproductive guild of simple and lithophilous groups of fish was most affected by increased siltation. This could be explained by the fact that members of this group require clean coarse substrate for spawning. No reproductive guild increased in abundance with an increase in sedimentation of silt/clay. The structure of the feeding guilds responded more to siltation than that of the reproductive guilds. Many species were both benthic invertivore or herbivore, and simple and lithophilous.

Other species of benthic invertivore guild such as B. africanus, P. leonensis and S. melanotheron all made use of crevices in substratum as nest, which may be readily impacted by siltation as are their food. Most of these showed parental care that is very highly specialized, e.g. fin fanning, and nipping and mouthing of eggs which, of course, reduces sedimentation-induced mortality. This approach of using the association and levels of sedimentation with the ecological guilds of feeding and reproductive behaviours to disruption of the substrate conditions, along with many significant correlations among impacted guild species that would be expected by chance, is suggestive of the validity in use of guild concept to evaluate anthropogenic perturbations in the estuarine ecosystem. By this present study, an approach is advanced of the relative success of using various fish species affected by siltation to predict estuarine faunal response to habitat alteration of this nature.

\section{Acknowledgement}

The project was carried out during the National Agricultural Research Programme (NARP) funded and headed by Prof. Seighaw Holslothner of the Institute of Oceanography, University of Calabar, to whom the author is duly grateful. Thanks are also due to Dr Abby-Kalio for reviewing the manuscript. Special thanks are due to Mrs Eme Ewa-Oboho, Victor and Emman-Oboho for their great moral support. Prof. Effiom Antia provided administrative support. The spiritual and moral support of Mrs H. Ukpabio of the Liberty Foundation Gospel Ministries in Calabar, Nigeria is especially appreciated.

Asuquo F. E. (1998). Physico-chemical characteristics and anthropogenic pollution of the surface waters of Calabar River, Nigeria. Global $J$. Pure Appl. Sci. 5: 595-600.

Asuquo F. E., Ewa-Oboho 1. O. and Udo P. (2004). Fish species used as biomakers for heavy metal and hydrocarbon contamination in the Cross River Estuary, Nigeria. The Environ. 24: 29-37.

Allen K. R. (1969). Distinctive aspects of the ecology of stream fishes: a review J. Res. Board. Com. 26: 1429-1438.

Brusven M. A. and Prather K. V. (1974). Influence of stream sedimentation distribution on macrobenthos. J. Entomol. Soc. B.C. 71: 25-32.

Cairns J. and Dickson C. J. (1980). The ABC's of biological monitoring. In Biological monitoring of Fish. (C. H. Hocutt and J. R. Stauffer Jr., ed.), pp. 205-231. Lexing ton Books. Lexington.

Chutter F. M. (1969). Effects of silt and sand on the invertebrates fauna of streams and rivers.

Cordone A. J. and Kelley D. W. (1961). The influences of organic sediment on the aquatic life in streams. Calif Fish Game 47: 189-228.

Culp J. M and Davis R. W. (1980). Reciprocal averaging and polar ordination as techniques for analyzing lotic macro invertebrate communities Can J. Fish Aqua Sci. 37: 1358-1364.

Ellis M. M. (1936). Erosion silt as a factor in aquatic environments. Ecology 17: 27-42.

Ewa-Oboho. I. O (1992). Substratum preferences of two tropical estuarine crabs, Uca tangeri Eydoux and Docypode Cursor. Hydrobiologia 27: $119-127$.

Gauch H. (1983). Multivariate analysis in community ecology. Cambridge University Press. New York 298 pp.

Gorman O. T. and Karr J. R. (1978). Habitat Structure and Stream fish’ communities. Ecology 59: 507-518.

Hendricks M. L., Hocutt C. H. and Stanffer R. J. (1980). Monitoring of fish in lotic habitats. In Biological Monitoring of Fish. (C. H. Hocutt and J. R. Stanffer, ed.), pp. 205-231. Lexington Books. Lexington.

Hillary E. B. and Rabeni C. F. (1987). Effects of siltation on stream fish communities. Environ. Biol. Fish 18: $285-294$. 


\section{West Africa Journal of Applied Ecology (WAJAE) -ISSN: 0855-4307 \\ Volume 9 (Jan - Jun 2006) \\ WwW.wajae.org}

Hill M. O. (1979a). Reciprocal averaging: an eigenvector method of ordination. J. Ecology 61: 237-249.

Hill M. O. (1979b). DECORANA - a Fortran program for detrended correspondence analysis and reciprocal averaging. Section of Ecology and Systematics, Cornell University, Ithaca.

Holzlohner S., Nwosu F. N. and Akpan R. E. (2002). Mangrove mapping of Cross River estuarine ecosystem. Afor. J. Environ. Pollut. Health 1(2): 76-87.

Judy R. D., Seeley M. T., Snirsky S. C., Whitworth M. R. and Ischinger L. S. (1984). National Fisheries Survey, Volume 1. Technical Report: Initial findings U. S. Fish Wildl. Service; FWs/OBS-84/06.140 pp.

Moyle P. B. and Senanayaka F. R. (1984). Resource participating among fishes of rainforest sreams in Sri Lanka. J. Zool. (Lond.) 202: 195223.

Karr J. R. (1981). Assessment of biotic integrity using fish communities. Fisheries (Bethesda) 6: 21-31.

Karr J. R. and Dudley R. D. (1981). Ecological perspective on water quality goals Environ. Mgmt 5: 55-68.

Langlois T. H. (1941). Two processes operating for the reduction in abundance or elimination of fish from certain type of water areas. Trans. Amer. Wildl. Conf. 6: 189-201.

Muncy R. J., Akinson R. V., Bulkley B. W. and Menzel L. G (1999). Effects of suspended solids and sediment on reproduction and early life of warm water fishes: a review. EPA-600/3-99-0 Corvallis. Environmental Research Laboratory, Corvallis. 100 pp.

Rabeni C. F. and Gibbs E. K. (1980). Ordination of Deep river invertebrate communities in relation to environmental variables. Hydrobiologia 74: $67-78$.

Schlosser I. J. (1982). Trophic Structure, reproductive success and growth rate of fishes in a natural and modified headwater stream. Can. J. Fish. Aquatic Sci. 39: 968-978.

Sheridan G. C., Lee C., Wakeham S. G. and Bishop J. K. (2002). Suspended particles, organic composition and cycling in surface waters of ocean. Deep Sea Reg. 149: 1983-2008.

Smith P. W. (1971). Illionois stream: a classification based on their fishes and analysis of factors responsible for disappearance in native species. III. Nat. Surv. Biol. Notes 76: 14 pp.

Spalding M. D. (1999). The global distribution and status of mangrove eecosystems. Intercoast Network 1: 20-21.

Starret W. C. 1950. Food relationships of the minnows of the Des Moines River. Iowa Ecol. 31:216-233.

Stauffer J. R. and Hocutt C. H. (1980). Initia and recovery: an approach to stream classification and stress evaluation. Water Resource. Bull. 16: 72-78. 